\title{
Conway's game of life and the ecosystem represented by Uexküll's concept of Umwelt
}

\author{
Solomon Marcus \\ Section of Mathematical Sciences, Romanian Academy, \\ Calea Victoriei 125, 71102 Bucuresti, Romania \\ e-mail: solomon.marcus@imar.ro
}

\begin{abstract}
Inspired by a mathematical ecology of theatre (M. Dinu) and the eco-grammar systems (E. Csuhaj-Varju et al.), this paper gives a brief analysis of simple cellular automata games in order to demonstrate their primary semiotic features. In particular, the behaviour of configurations in Conway's game of life is compared to several general features of Uexküll's concept of Umwelt. It is concluded that ecological processes have a fundamental semiotic dimension.
\end{abstract}

Traditionally, ecology has been considered as making a sharp distinction between subject and object and, consequently, between the living being and its environment. This conception of an ecosystem can be illustrated by various mathematical models. Among these, however, a few are of special interest, for instance, one based on a theatrical scenario (Dinu 1974) and another that is expressed in terms of grammar systems (Csuhaj-Varju et al. 1994).

In Dinu's approach, an ecosystem is conceived as a biophysical structure including two different subsystems: a physical subsystem, the habitat, and a bio-subsystem, biocenosis, that contains the totality of populations existing in the respective habitat. An analogy between the behaviour of the biological communities and the behaviour of the characters in a theatrical play makes it possible to apply in ecology some mathematical models of the semiotics of theatre, as conceived by Marcus (1967, 1969, 1970: 257-327) and Dinu (1968, 1970). The basic objects in the model are a set $T$ of points, the territory, and the 
set $S$ of all species living in $T$. A relation $r$ associates to each species $S$ in $S$ a part of $T$, the area $r(s)$ of distribution of $s$. It is shown how the relations between species are influenced by the set of all possible biocenoses in $T$.

In the second model, proposed by Csuhaj-Varju et al. (1994) and further developed in several subsequent papers (e.g., Csuhaj-Varju et al. 1997), an ecosystem is an articulation of several agents and an environment. Agents are ruled by some evolution rules, by parallel rewriting and by a description, while the environment includes action rules, a sequential rewriting, a description, a parallel rewriting and some evolution rules. In this way, both the agents and the environment have the structure of an automaton and the whole construct is systemic. This includes self-referential behaviour and interaction between the agents.

The proposed ecosystem model shares the theatrical aspect of Dinu's model and the generative nature of Csuhaj-Varju's model. It adopts John Conway's famous game of life with its interpretation as an Umwelt in the sense of Jakob von Uexküll. The advantage of this procedure, as we show, stems from the fact that Conway's game of life fulfils many requirements to be considered as an Umwelt, together with its specific aspects contrasting "Umwelt" with "Environment" (Uexküll 1982; Marcus 2001).

\section{From von Neumann to Conway}

Conway's life automaton simulates the life-like behaviour by its capacity to permit self-reproduction. It is the simplest model in a series of such devices, inaugurated by von Neumann, whose first work in this respect was published in 1948, but we will refer here to his more comprehensive presentations $(1958,1966)$. We learn from Odifreddi (1997: 53) that Schrödinger (1944) and von Neumann (1948) had some influence on Watson and Crick (1953) with their famous discovery of the double-helix structure of DNA. Von Neumann (1958) tried to build a self-reproducing mechanical automaton by articulating three machines: $A, B$ and $C$. Machine $A$ is a universal constructor that, when fed the description $d(X)$ of a machine $X$, builds $X$. Machine $B$ reproduces any description given to it. Machine $C$ coordinates $A$ and $B$; given a description $d(X), A$ builds a copy of $X$, while $B$ reproduces a copy of $d(X)$, after which the copy of $X$ is fed the 
copy of $d(X)$. Denoted by $D$, the resulting machine $A+B+C,(D, d(D))$ is self-reproducing. This presentation is attributed to Odifreddi (1997: 53-54), who observes that what von Neumann hypothesised and Watson and Crick confirmed is that this is a simplified representation of genetic reproduction: living cells contain universal constructors, basically the same for plants and animals, and only the genetic material (the program) is different; $d(X)$ works like a segment of DNA that codifies the reproduction information, $B$ (a special enzyme RNA polymerase) has the function of duplicating the genetic material into a segment of RNA, while $A$ (a set of ribosomes) builds proteins by following (a segment of RNA containing) the reproduction information. The resulting machine is a self-reproducing cell.

The questionable point of this model is the assumption of the existence of a universal constructor. This difficulty is transgressed by von Neumann (1966), who envisions a series of events taking place in a space of cells. In this respect, he uses a so-called cellular automaton, which is a potentially infinite, directed graph (space), whose nodes (cells) are finite state machines. Each cell can be in various states and the global behaviour consists of simultaneous, co-ordinated changes in the states of the individual cells. Specifically, von Neumann considers an automaton represented in a planar space with 29-state cells of a single type, each connected to the four orthogonally adjacent neighbours. He found a finite quiescent configuration (of around 200,000 cells) that, given any other finite quiescent configuration, reproduces it in a different part of the space, without erasing itself: he thus found a universal constructor for the class of quiescent configurations (Odifreddi 1997: 54-55).

Just as in von Neumann's order of ideas is Conway's life automaton, admitting self-developing configurations (Berlekamp et al. 1982; Poundstone 1984). The name reveals that it simulates life-like behaviour. It is also called Conway's game of life (GOL), because it has features of a strategic game. It consists of a planar space with each cell connected to the eight adjacent cells. Each cell has two states: 0 (death) and 1 (life). GOL is governed by two rules: (a) a dead cell is born when exactly three neighbours are alive; (b) a live cell survives if and only if two or three neighbours are alive. These rules dictate that the life of a cell is possible only if the number of living cells in its neighbourhood is neither overly small nor large. Both overpopulation and isolation produce death.

Three possibilities exist for a population in GOL: death, cyclic behaviour, and reproductive expansion. As Odifreddi asserts: 
Life is about as simple as it can be (it is well-known that 2-states cells with a von Neumann neighbourhood do not admit non-trivial self-reproduction), and it shows that self-reproduction does not need a complicated universe (since it is logically possible from simple physical models). (Odifreddi 1977: 55)

\section{The game of life as Umwelt}

Conway's GOL agrees with Jakob von Uexküll's concept of Umwelt in several respects.

(1) Like Umwelt, GOL makes no essential, intrinsic distinction between a population and its surroundings, between living beings and nature, between subject and object. Due to its capacity of expansion, a given population $P$ is potentially everywhere; the surrounding $s(P)$ of $P$ is potentially a part of $P$, because it includes cells which, in spite of being referred to as "dead cells", are only asleep, i.e., ready to wake up and become active in $P$. On the other hand, other cells, active in $P$, may fall asleep, moving from $P$ to $s(P)$. Because the border between $P$ and $s(P)$ is modified at each step, it is more convenient to consider that each basic square in the imaginary map of the eco-space created by $P$ belongs equally to $P$ and to $s(P)$.

(2) Like Uexküll's Umwelt, Conway's GOL is purely relational: nature is only indirectly perceived, via its relations to the living cells. The process to approach nature is purely semiotic. The evolution of the interplay between living cells and their neighbours is the only sign process by means by which nature is perceived by $P$.

(3) In contrast with classical ecology, where the ecosystem is relatively separated from the living beings to which it is associated, living beings are solitary in Uexküll's conception, the ecosystem of $P$ being a product of $P$. This is what happens under GOL, where the initial configuration of $P$ determines all its possible further evolutions. If the configuration of $P$ tells us, by using rule (b), the possibilities of cells in $P$ to survive, the configuration shows also, by rule (a), to what extent new living cells will be added to $P$.

(4) Like Umwelt, the configuration of $P$ and $s(P)$ is permanently modified, although this fact also includes a remarkable particular case in which the respective configuration is stationary.

(5) Like Umwelt, the ecosystem represented by GOL is confrontational, because it has to face two opposite requirements: the difficulty of its emergence and the danger of its deterioration (by other eco- 
systems). No population is isolated in the world; different populations may clash. Any place potentially belongs to the ecosystem of any possible individual of any possible population. Even if we consider only one population $P$, rules (a) and (b) express two opposite trends, rule (a) shows the need of $P$ to spread, while rule (b) expresses the need of $P$ to survive, facing the danger to die.

(6) The possibility for $P$ to spread beyond any limits in all directions, one of the basic trends in Conway's GOL, is in agreement with the openness of any ecosystem, so important in the modern mentality, and particularly in Uexküll's ideas about Umwelt.

(7) The theatrical metaphor, used by Uexküll in order to illustrate the confrontational nature of Umwelt, meets the attempts to view ecological processes as a theatrical performance (Hutchinson 1965; Dinu 1974).

(8) Uexküll's semantic atom, understood as the code that governs the life of a cell, has its analogy in Conway's GOL, which refers to cells placed in the squares of a checkerboard. As we have observed (Marcus 2001), this fact opens the possibility to take the semiotic atom as a unit of measure of the semiotic complexity of an ecosystem.

Both Umwelt and GOL display the features of life as viewed by Farmer and Belin (1992) and pointed out in the structure of von Neumann's cellular automaton; life is a pattern rather than a specific material object. Self-reproduction; metabolism; interdependence of parts in order to preserve identity, including the ability to die; ability to evolve; information storage of a self-representation (e.g., the selfdescription of the organism in DNA molecules which is interpreted in the protein/RNA machinery).

A requirement formulated by Farmer and Belin (1992), that of stability under perturbations and insensitivity to small changes, agrees only partially with the above approach above, because the principle of GOL is to accept only small changes having tremendous consequences (the "butterfly effect"; see the crucial role of the numbers 2 and 3 in the formulation of the rules (a) and (b)). This may mean that life is not always gradually separated from death, the move from the former to the latter may be chaotic, in the sense of the theory of nonlinear dynamical systems.

Given the considerations above, we infer that - to the extent to which the life is a semiotic phenomenon, as conjectured by Thomas Sebeok, Jesper Hoffmeyer, Claus Emmeche, Winfried Nöth and Kalevi Kull and in agreement with the ideas developed by Jakob von 
Uexküll and John von Neumann - ecological processes also have a fundamental semiotic dimension.

\section{References}

Berlekamp, Elwyn R.; Conway, John Horton; Guy, Richard K. 1982. Winning Ways, for your Mathematical Plays. London: Academic Press.

Csuhaj-Varju, Erzsebet; Kelemen, Jozef; Kelemenová, Alice; Păun, Gheorghe 1994. Eco(grammar) systems: A preview. In: Trappl, Robert (ed.), Cybernetics and Systems '94. Singapore: World Scientific Publ., 941-948.

Csuhaj-Varju, Erzsebet; Kelemen, Jozef; Kelemenová, Alice; Paun, Gheorghe 1997. Eco-grammar systems: A grammatical framework for studying life-like interactions. Artificial Life 3: 1-28.

Dinu, Mihai 1968. Structures linguistiques probabilistes dans l'étude du théatre. Cahiers de linguistique théorique et appliquée 5: 29-46.

- 1970. Contributions a l'étude mathematique du théatre. Revue Roumaine de Mathematiques Pures et Appliquees 15 (5).

- 1974. Éléments pour une écologie mathématique. Informatica si modele matematice in stiintele sociale [Informatics and Mathematical Models in Social Sciences] 3(1/2): 43-53.

Farmer, J. Doyne; Belin, Alletta d'A. 1992. Artificial life: The coming evolution. In: Langton, Christopher G.; Taylor, Charles; Farmer, J. Doyne; Rasmussen, Steen (eds.), Artificial Life II. (Santa Fe Institute Studies in the Sciences of Complexity, Proceedings 10.) Redwood City: Addison-Wesley, 815-840.

Hutchinson, G. Evelyn 1965. The Ecological Theater and the Evolutionary Play. New Haven: Yale University Press.

Marcus, Solomon 1967. Methodes mathématiques dans l'étude du drame. T. A. Informations: Revue Internationale du Traitement Automatique du Language 2: 86-87.

- 1969. Metode matematice in studiul dramei: Strategia personajelor I. In: Metodologia istoriei şi a criticii literare. Bucureşti: Editura Academiei, 163170.

- 1970. Poetica Matematica. Bucuresti: Editura Academiei.

- 2001. On the logical and semiotic status of Jakob von Uexküll's concept of Umwelt. Semiotica 134(1/4).

Neumann, John von 1948. The General and Logical Theory of Automata. Cambridge: M.I.T. Press.

- 1958. The Computer and the Brain. New Haven: Yale University Press.

- 1986. The Theory of Self-Reproducing Automata. Chicago: University of Illinois Press.

Odifreddi, Piergiorgio 1997. Indiscreet applications of discrete mathematics. In: Bridges, D.S.; Calude, Cristian S.; Gibbons, J.; Reeves, S.; Witten, I.H. (eds.), Combinatorics, Complexity, Logic: Proceedings of DMTCS'96. Singapore: Springer, 52-65. 
Poundstone, William 1984. The Recursive Universe: Cosmic Complexity and the Limits of Scientific Knowledge. New York: William Morrow.

Schrödinger, Erwin 1944. What is Life? Cambridge: Cambridge University Press.

Uexküll, Jakob von 1982. The theory of meaning. Semiotica 42(1): 25-82.

Watson, James D.; Crick, Francis H. C. 1953. Molecular structure of nucleic acids: A structure for deoxyribose nucleic acid. Nature 171: 737-738.

\section{“Игра жизни” Конвея и \\ представление экосистемы с помощыо концепта Umwelt}

Отталкиваясь от математической экологии в применении к театру (M. Dinu) и экограмматических систем (E. Csuhaj-Varju и др.), в статье анализируются игры, базирующиеся на клеточных автоматах, с целью демонстрации их семиотических свойств. Рассматривается поведение фигур в "игре жизни" Джона Конвея в сравнении с некоторыми свойствами модели Umwelt Юкскюля. Вывод - экологические процессы имеют семиотическое измерение.

\section{Conway "elu mäng" ja ökosüsteemi esitus Uexkülli omailma mudeli abil}

Inspireerituna matemaatilise ökoloogia rakendamisest teatri uurimisel (M. Dinu) ja ökogrammatilistest süsteemidest (E. Csuhaj-Varju et al.), analüüsitakse artiklis lühidalt rakuautomaatidel põhinevaid mänge, üritades demonstreerida nende semiootilisi omadusi. Vaadeldakse John Conway "elu mängu" figuuride käitumist ning võrreldakse seda mõnede Uexkülli omailma mudeli omadustega. Järeldatakse, et ökoloogilistel protsessidel on olemas semiootiline mõõde. 